\title{
Aberrant expression of glycogen synthase kinase-3 $\beta$ in human breast and head and neck cancer
}

\author{
ANDREY V. UGOLKOV ${ }^{1,2}$, MARIA MATSANGOU ${ }^{1}$, TIMOTHY J. TAXTER ${ }^{3}$, THOMAS V. O'HALLORAN ${ }^{2,4}$, \\ VINCENT L. CRYNS ${ }^{5}$, FRANCIS J. GILES ${ }^{1,4}$ and ANDREW P. MAZAR ${ }^{2,4,6,7}$

\begin{abstract}
${ }^{1}$ Department of Medicine, Division of Hematology/Oncology, Feinberg School of Medicine, Northwestern University, Chicago, IL 60611; ${ }^{2}$ Chemistry of Life Processes Institute, Northwestern University, Evanston, IL 60208; ${ }^{3}$ Department of Pathology, Feinberg School of Medicine, Northwestern University; ${ }^{4}$ Robert H. Lurie Comprehensive Cancer Center, Northwestern University, Chicago, IL 60611; ${ }^{5}$ Department of Medicine, University of Wisconin Carbone Cancer Center, University of Wisconsin School of Medicine and Public Health, Madison, WI 53726; ${ }^{6}$ Monopar Therapeutics, Inc., Wilmette, IL 60091; ${ }^{7}$ Department of Pharmacology, Feinberg School of Medicine,
\end{abstract} \\ Northwestern University, Chicago, IL 60611, USA
}

Received May 4, 2018; Accepted September 18, 2018

DOI: $10.3892 / \mathrm{ol} .2018 .9483$

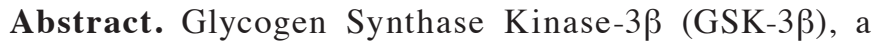
serine/threonine protein kinase, has been implicated as a potential therapeutic target in human cancer. The objective of the present study was to evaluate aberrant expression of GSK- $3 \beta$ as a potential biomarker in human breast and head and neck cancers. Nuclear/cytosolic fractionation, immunoblotting and immunohistochemical staining was used to study the expression of GSK-3 $\beta$ in human breast and head and neck cancer. Aberrant nuclear accumulation of GSK-3 $\beta$ in five human breast cancer cell lines was demonstrated and in 89/128 (70\%) human breast carcinomas, whereas no detectable expression of GSK-3 $\beta$ was found in benign breast tissue. Nuclear GSK-3 $\beta$ expression was associated with HER-2 positive tumors $(\mathrm{P}=0.02)$ and non-triple negative breast carcinomas $(\mathrm{P}=0.0001)$, although nuclear GSK-3 $\beta$ was observed in some samples across all breast cancer subtypes. Aberrant nuclear expression of GSK-3 $\beta$ was found in 11/15 (73\%) squamous cell head and neck carcinomas, whereas weak or no detectable expression of GSK-3 $\beta$ was found in benign salivary gland and other benign head and neck tissues. These results support the hypothesis that aberrant nuclear GSK-3 $\beta$ may represent a potential target for the clinical treatment of human breast and squamous cell carcinoma.
\end{abstract}

Correspondence to: Dr Andrew P. Mazar, Monopar Therapeutics, Inc., 1000 Skokie Boulevard, Wilmette, IL 60091, USA

E-mail:mazar@monopartx.com

Key words: GSK-3, nuclear, expression, breast cancer, head and neck cancer

\section{Introduction}

Breast cancer is the second leading cause of cancer death in the US (1). Squamous cell carcinoma and salivary gland malignancies are common types of head and neck cancer (2). For advanced or metastatic disease, there are limited acceptable therapeutics options $(1,2)$. These types of cancer represent a significant unmet medical need and the identification of new molecular targets and targeted therapies are urgently needed.

Glycogen Synthase Kinase-3 (GSK-3), a serine/threonine protein kinase, has been identified as a regulator of diverse cellular functions (3). GSK-3 $\alpha$ and GSK-3 $\beta$ are two highly homologous forms of GSK-3 in mammals (3). Historically, GSK-3 $\beta$ had been thought to be a potential tumor suppressor, via suppression of pro-oncogenic molecules such as cyclin D1 (4), $\beta$-catenin (5) and c-Myc (6). However, recent research has implicated GSK-3 $\beta$ as a potential therapeutic target in cancer (7-18). Disruption of the GSK-3 $\beta$ gene in mice resulted in embryonic lethality due to hepatocyte apoptosis copying the mouse phenotype produced by a deletion of genes involved in NF-kB activation (19). These findings suggested a potential link between GSK-3 $\beta$ and NF- $\kappa B$ activation in cancer. NF- $\kappa B$ activation is known to promote human cancer progression, metastasis, and chemoresistance $(20,21)$. The exact mechanism by which GSK-3 $\beta$ impacts NF- $\mathrm{\kappa B}$ activity is still unclear. However, previous studies suggested that NF- $\kappa B$ might be regulated by GSK- $3 \beta$ at the level of the transcriptional complex in the nucleus (19). It has been demonstrated that only the active form of GSK-3 $\beta$ accumulates in the nucleus of pancreatic cancer cells and the inhibition of GSK-3 $\beta$ activity depletes this nuclear pool via proteosomal degradation whereas the expression level of cytoplasmic GSK-3 $\beta$ is not changed (10). In human leukemia cells, GSK-3 $\beta$ inhibition leads to the depletion of GSK-3 $\beta$ from the cancer cell nucleus and abrogated NF- $\mathrm{kB}$ binding to promoters on its target genes XIAP and Bcl-2, in part through modification of histones, leading to a decreased expression of these molecules (11). 
These studies have led to a hypothesis that nuclear GSK-3 $\beta$ may be the actual target for GSK-targeting therapy. Here, our results have identified aberrant nuclear GSK-3 $\beta$ expression as a potential biomarker for breast and squamous cell carcinomas of the head and neck. Small molecule inhibitors of GSK-3 are currently in clinical development for the treatment of human cancer and other diseases (22-24). The clinical utility of nuclear GSK-3 $\beta$ expression as a biomarker of breast and squamous cell carcinoma of the head and neck remains to be established. However, nuclear GSK-3 $\beta$ expression may represent a novel enrichment marker for selecting patients most likely to benefit from GSK-3-targeted therapy, such as 9-ING-41.

\section{Materials and methods}

Immunohistochemical staining. Immunohistochemical (IHC) staining was performed on paraffin sections of three tissue microarrays (TMA) representing 128 cases of human breast cancer (BioChain Institute Inc., Newark, CA, USA; TMA maps https://www.biochain.com/wp-content/uploads/datasheet/Z7020005-B410018.pdf and https://www.biochain. com/wp-content/uploads/datasheet/T8235721-2-B904111.pdf) and 48 cases of benign and malignant tumor tissues of the neck, oranasopharynx, larynx and salivary glands (BioChain Institute Inc.; TMA map https://www.biochain. com/wp-content/uploads/datasheet/Z7020051-B508149.pdf). TMA sections were deparaffinized, and antigen retrieval was carried out in citric buffer in microwave for $10 \mathrm{~min}$. The sections were incubated in $1 \%$ hydrogen peroxidase for $10 \mathrm{~min}$ to quench endogenous tissue peroxidase. TMA sections were then incubated with the anti-GSK-3 $\beta$ antibody (Cell Signaling Technology, Inc., Danvers, MA, USA) overnight at $4^{\circ} \mathrm{C}$. The slides were stained using a standard EnVision+ System-HRP kit (Agilent Technologies, Inc., Santa Clara, CA, USA) according to the manufacture's protocol. Immunohistochemical reactions were developed with diaminobenzidine as the chromogenic peroxidase substrate, and slides were counterstained with hematoxylin. Negative control samples included replacement of the primary antibody with nonimmune IgG1 (Agilent Technologies, Inc.). We defined GSK-3 $\beta$ nuclear accumulation as positive staining of $>50 \%$ of cancer cell nuclei throughout the tumor sample regardless of cytoplasmic staining.

Cell lines, immunoblot analysis and antibodies. Breast cancer cell lines MCF7, MDA-MB-231, SKBR3 and GILM2 were obtained from American Type Culture Collection (ATCC, Manassas, VA, USA). For immunoblots, cells were lysed as described previously (7). Nuclear/cytosolic fractionation was performed using the Dignam method (25). Protein sample concentration was determined by Bradford protein assay and equal amounts (50 $\mu \mathrm{g}$ nuclear or cytosolic protein extract) of protein were loaded in each well of a SDS-polyacrylamide gel. Cell extracts were separated by $10 \%$ SDS-PAGE, transferred to PVDF membranes, and probed as indicated. The following antibodies were used for immunoblot analysis: GSK-3 $\beta$ (cat. no. 12456; Cell Signaling Technology, Inc.); and histone H3 (cat. no. ab1791; Abcam, Cambridge, MA, USA). Bound antibodies were detected as described previously (7). Because nuclear/cytosolic fractionation can be performed only using freshly resected human tumor samples which were not available for this study, we analyzed expression of GSK-3 $\beta$ by IHC staining in formalin-fixed paraffin-embedded human tumor sections in vivo and by nuclear/cytosolic fractionation and western immunoblotting in cancer cell lines in vitro.

Statistical analysis. Associations between GSK-3 $\beta$ immunohistochemical staining and clinicopathological parameters were analyzed using Fisher's exact test. $\mathrm{P}<0.05$ was considered to indicate a statistically significant difference. Statistical analysis was performed using GraphPad Prism v6.0 software (GraphPad Software, Inc., La Jolla, CA, USA).

\section{Results}

Aberrant nuclear expression of GSK-3 $\beta$ in breast cancer cells. Recently, GSK-3 $\beta$ has been credentialed as a potential therapeutic target in human breast cancer (26-28). Here, we used immunohistochemical staining to analyze the expression and subcellular localization of GSK-3 $\beta$ in 128 primary breast carcinomas (Table I). Of 128 breast carcinomas analyzed, 89 (70\%) showed aberrant nuclear expression of GSK-3 $\beta$ (Table I, Figs. 1 and 2A). Nuclear GSK-3 $\beta$ expression was most strongly associated with HER-2 positive tumors $(\mathrm{P}<0.05)$ and non-triple negative breast carcinomas $(\mathrm{P}<0.05)$, although nuclear GSK-3 $\beta$ was observed across all breast cancer subtypes (Table I). In addition, we found nuclear expression of GSK-3 $\beta$ in primary tumors and corresponding lymph node metastases obtained from 8 breast cancer patients ( 4 cases were ER+/PR+/HER2+ and 4 cases were ER-/PR-/HER2-according to the information obtained from patient's pathology report) (Fig. 2B and C). We did not observe GSK-3 $\beta$ nuclear accumulation in mammary ducts, glands and other benign cells within a breast tumor (Fig. 1A). Because it is particularly important to compare expression of GSK-3 $\beta$ in benign structures adjacent to clumps of cancer cells on the same tumor section, we selected such an area of breast carcinoma (Fig. 1A) as a representative picture of nuclear GSK-3 $\beta$ expression in breast cancer cells and hardly detectable cytoplasmic expression of GSK-3 $\beta$ in benign mammary glands. Only cytoplasmic expression of GSK-3 $\beta$ was detected in breast fibroadenomas. Our results suggest that aberrant nuclear accumulation of GSK-3 $\beta$ is a feature of breast cancer cells and therefore might serve as a potential biomarker in human breast cancer. In support of our TMA results, we also found aberrant nuclear accumulation of GSK-3 $\beta$ in a panel of human breast cancer cell lines (Fig. 1B).

Altered expression of GSK-3 $\beta$ in head and neck tumors. Head and neck TMA consisted of benign tissues, 17 different benign tumors (nasal polyps, hemangioma, neurofibroma, schwannoma and pleomorphic adenoma) and 29 different malignant tumors including squamous cell carcinoma (15 cases), adenoid cystic carcinoma (5 cases), sarcoma (2 cases), nasopharyngeal carcinoma (1 case), mucoepidermoid carcinoma (1 case), lymphoma ( 2 cases), metastatic tumors (3 cases). Using immunohistochemical staining, only weak cytoplasmic or no detectable expression of GSK-3 $\beta$ was observed in benign salivary ducts, serous and mucous acini (Fig. 3A). In great contrast to benign tissue, GSK-3 $\beta$ nuclear accumulation was observed in 11 of $15(73 \%)$ cases of squamous cell carcinoma and in 
Table I. Association between GSK-3 $\beta$ nuclear expression and clinicopathological characteristics in primary breast carcinoma.

\begin{tabular}{|c|c|c|c|}
\hline \multirow[b]{2}{*}{ Characteristics } & \multicolumn{2}{|c|}{ GSK-3 $\beta$ nuclear expression } & \multirow[b]{2}{*}{ P-value } \\
\hline & Positive & Negative & \\
\hline Tumor stage & & & NS \\
\hline $\mathrm{T} 1$ & 11 & 2 & \\
\hline $\mathrm{T} 2$ & 65 & 33 & \\
\hline $\mathrm{T} 3$ & 13 & 4 & \\
\hline Lymph node metastasis & & & NS \\
\hline No & 57 & 24 & \\
\hline N1-N3 & 32 & 15 & \\
\hline Distant metastasis & & & NS \\
\hline M0 & 80 & 34 & \\
\hline M1 & 9 & 5 & \\
\hline Tumor histology & & & NS \\
\hline Well differentiated & 7 & 1 & \\
\hline Moderately differentiated & 64 & 25 & \\
\hline Poorly differentiated & 18 & 13 & \\
\hline Estrogen receptor expression & & & NS \\
\hline Positive & 19 & 11 & \\
\hline Negative & 70 & 28 & \\
\hline HER2 expression & & & 0.0215 \\
\hline Positive & 19 & 2 & \\
\hline Negative & 70 & 37 & \\
\hline TN carcinoma & & & 0.0001 \\
\hline $\mathrm{TN}$ & 21 & 23 & \\
\hline Non-TN & 68 & 16 & \\
\hline
\end{tabular}

TN, Triple-negative; GSK-3 $\beta$, glycogen synthase kinase-3 $\beta$; HER2, human epidermal growth factor receptor 2.

3 of $5(60 \%)$ cases of adenoid cystic carcinoma (Fig. 3B). Only cytoplasmic expression of GSK-3 $\beta$ was observed in benign tumors such as neurofibroma ( 2 cases), schwannoma ( 2 cases) and nasal polyps (4 cases). However, nuclear accumulation of GSK-3 $\beta$ was observed in 4 of 8 cases (50\%) of pleomorphic adenoma, a common benign tumor of salivary gland with malignant potential.

\section{Discussion}

GSK-3 $\beta$ has been identified as a positive regulator of $\mathrm{NF}-\kappa \mathrm{B}-\mathrm{mediated}$ survival and chemoresistance of cancer cells (7,11-13). Previous reports demonstrated that GSK-3 $\beta$ positively regulates $\mathrm{NF}-\kappa \mathrm{B}$ transcriptional activity at a point downstream of the activation of the IkB kinase complex (7), suggesting a potential role for nuclear GSK-3 $\beta$ in the regulation of $\mathrm{NF}-\kappa \mathrm{B}$ transcriptional activity in the nucleus of cancer cell. It also has been shown that only the active form of GSK-3 $\beta$ accumulates in the nucleus of pancreatic cancer cells and the inhibition of GSK-3 $\beta$ activity depletes its nuclear accumulation via proteosomal degradation (10). Here, by immunohistochemical staining, we identified aberrant nuclear accumulation of GSK-3 $\beta$ in five breast cancer cell lines and in 89 of $128(70 \%)$ human breast carcinomas, whereas expression of GSK-3 $\beta$ was not detectable in benign breast tissue. Our findings are supported by previously published studies where aberrant GSK-3 $\beta$ nuclear accumulation was found only in pancreatic, renal, and bladder cancer cells, and malignant B-cells but not in corresponding benign cells (10-13). These results support the hypothesis that nuclear GSK-3 $\beta$ may represent a potential biomarker of breast cancer cells. Main findings of our study are based on IHC staining of TMAs. Although we haven't performed immunofluorescent staining of breast cancer cells in vitro, we analyzed GSK-3 $\beta$ subcellular localization using nuclear/cytosolic fractionation and Western immunoblotting with proper control represented by Histone $\mathrm{H} 3$, a specific marker of nuclear fraction (10). Our in vitro findings of nuclear GSK-3 $\beta$ expression in breast cancer cell lines are only supportive (not confirmative) for our in vivo findings (IHC staining of TMAs) because in vitro cancer cell culture (monoclonal) cannot truly represent heterogenous human malignant tumor in vivo. In a previously published immunohistochemical study of 1686 cases of breast cancer, overexpression of GSK-3 $\beta$ was associated with several indicators of poor prognosis including larger tumor size, lymph node metastasis, high pathological grade, ER-negative disease, PR-negative disease, increased proliferation and HER2 overexpression (27). Moreover, breast cancer patients with GSK-3 $\beta$ 


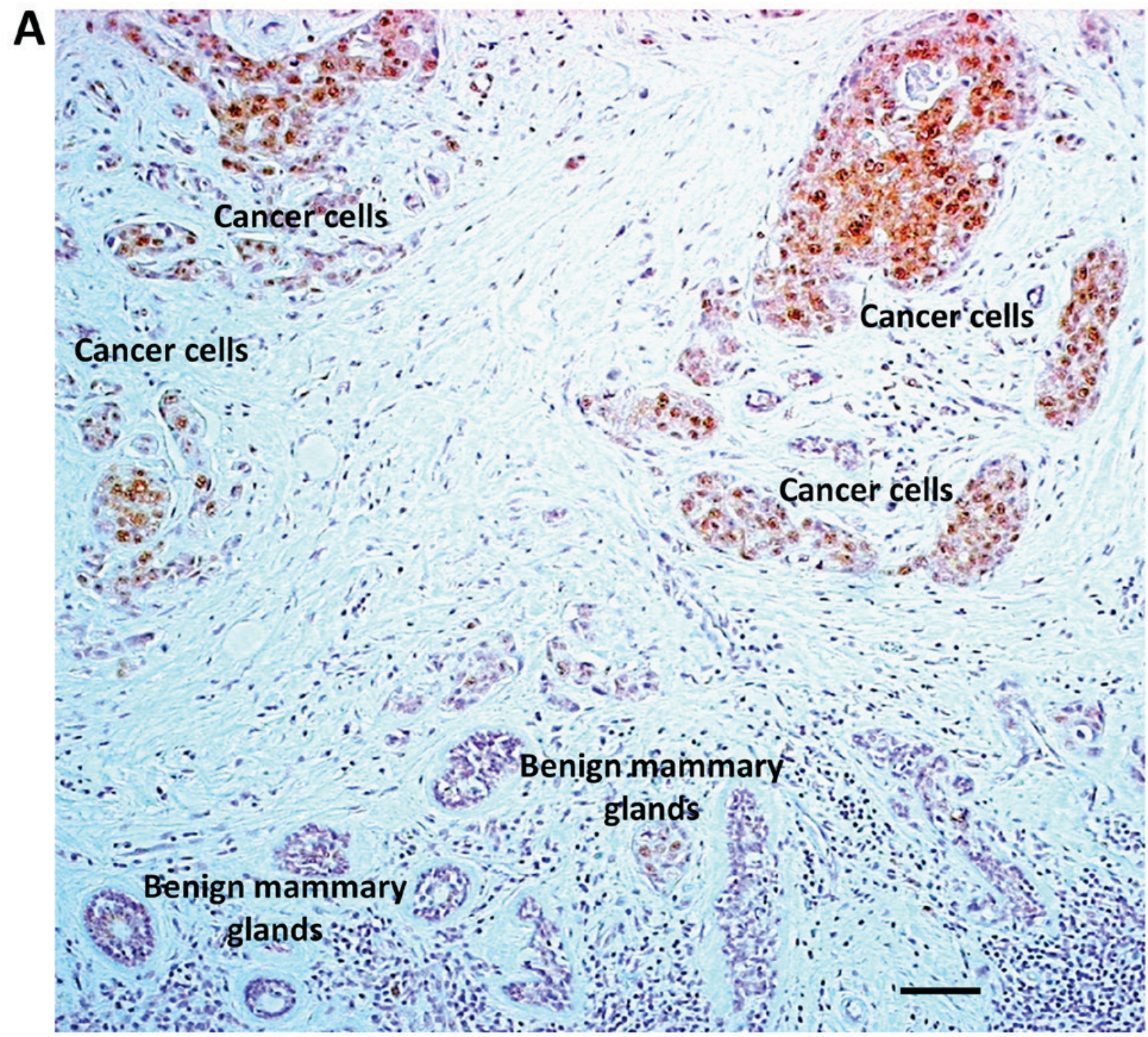

B

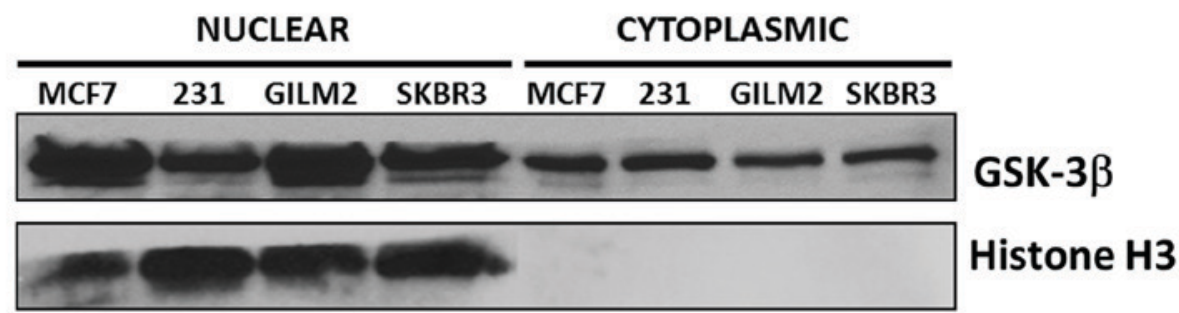

Figure 1. GSK-3 $\beta$ is aberrantly accumulated in the nucleus of breast cancer cells. (A) Representative image of GSK-3 $\beta$ expression and localization in primary breast carcinoma and adjacent benign breast tissue. Nuclear GSK-3 $\beta$ is expressed selectively in breast cancer cells. Scale bar, $50 \mu \mathrm{m}$. (B) Nuclear and cytosolic protein extracts were prepared from breast cancer cell lines, $50 \mu \mathrm{g}$ of nuclear and cytosolic proteins were separated by SDS-PAGE, transferred to PVDF membrane, and immunoblotted as indicated. GSK-3, Glycogen Synthase Kinase-3.

expression in the highest quartile (246 of 1,686 cases) had a 2.7-fold increased risk of distant relapse 5 years after tumor resection (27). This study did not differentiate between nuclear and cytoplasmic expression of GSK-3 $\beta$ but is consistent with previously published findings showing that GSK-3 $\beta$ nuclear expression was associated with high-grade tumors (pancreatic and bladder cancer), metastasis (bladder cancer), and poor prognosis (bladder cancer) $(10,12,13)$. From a technical perspective, nuclear accumulation of GSK-3 $\beta$ might be overlooked in the presence of cytoplasmic GSK-3 $\beta$ overexpression and/or heavy counterstaining with hematoxylin. The dark blue staining of cancer cell nuclei by hematoxylin using standard techniques (standard staining time is $5-8 \mathrm{~min}$ ) might mask light brown nuclear GSK-3 $\beta$ staining. In this study, we optimized the hematoxylin counterstaining step to decrease the intensity of hematoxylin nuclear staining by exposing the GSK-3 $\beta$-stained TMA to hematoxylin for $10 \mathrm{sec}$ in order to maximize the differentiation of the nuclear GSK-3 $\beta$ signal.

Because squamous cell carcinoma (common type of head and neck cancer) is a very rare histological type of breast cancer, 

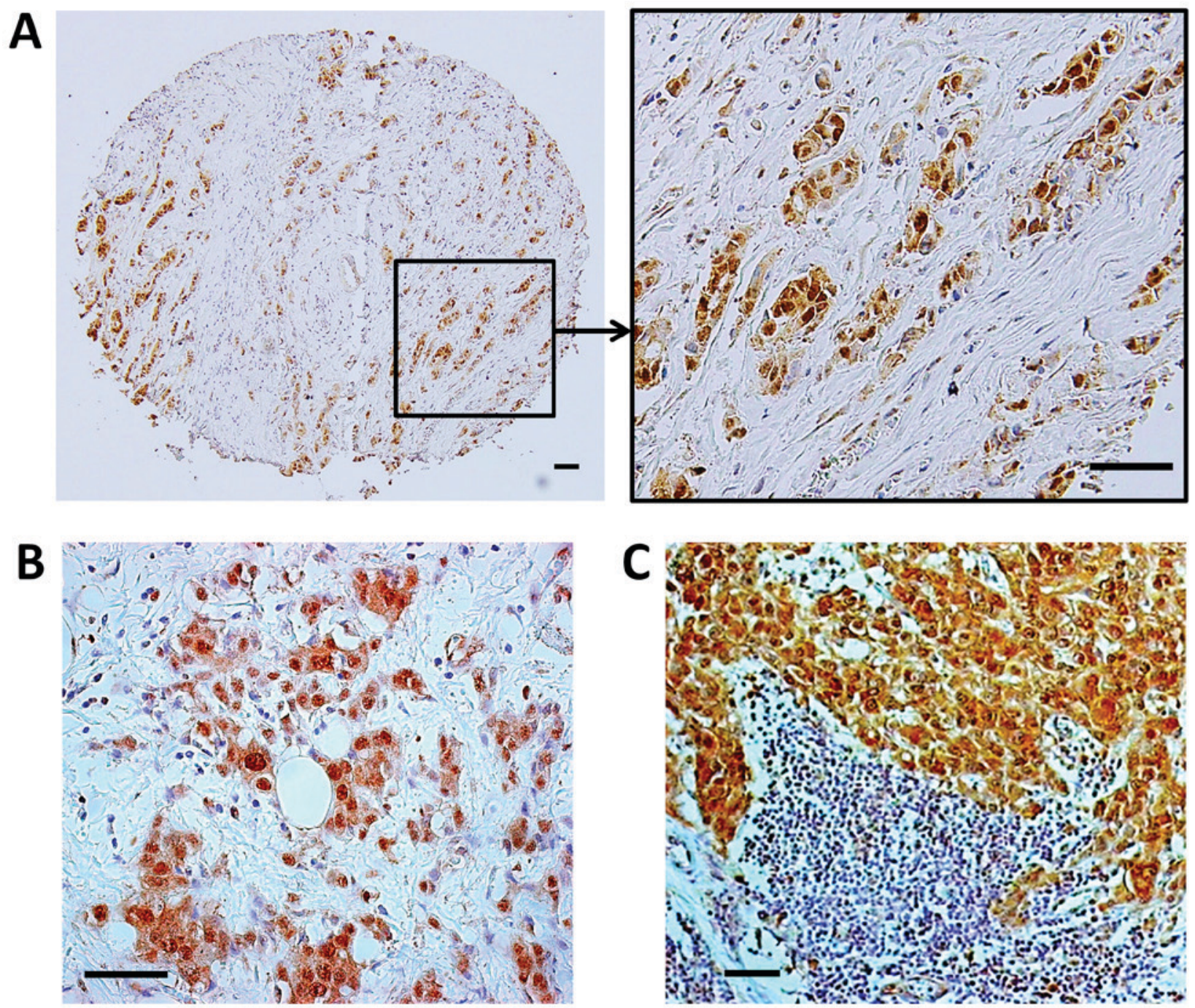

Figure 2. Nuclear expression of GSK-3 $\beta$ in human breast carcinoma. Representative pictures of nuclear GSK-3 $\beta$ expression in primary breast carcinoma, case 1 (A), and primary breast carcinoma, case 2 (B) with corresponding lymph node metastasis, case 2 (C). Scale bar, $50 \mu$ m. GSK-3, Glycogen Synthase Kinase-3.

we complemented our findings in breast cancer with the results of GSK-3 $\beta$ staining of head and neck TMA to explore aberrant expression of GSK-3 $\beta$ mainly in squamous cell carcinomas. Whereas only weak cytoplasmic or no detectable expression of GSK-3 $\beta$ was observed in benign salivary ducts, serous and mucous acini, GSK-3 $\beta$ nuclear accumulation was observed in 11 of $15(73 \%)$ cases of squamous cell carcinoma and in 3 of 5 $(60 \%)$ cases of adenoid cystic carcinoma. Although we cannot draw a statistically significant conclusion due to the limited number and different histotypes of head and neck malignant tumors, we believe that it is important to present our initial findings showing aberrant nuclear GSK-3 $\beta$ expression in head and neck cancer (with focus on squamous cell carcinoma) but not in benign tissues. This is the first exploratory IHC study to evaluate aberrant GSK-3 $\beta$ expression in head and neck tumors. Further larger scale studies of GSK-3 $\beta$ expression in head and neck cancer would warrant a meaningful statistical analysis to find a correlation of aberrant GSK-3 $\beta$ expression and clinicopathological parameters.

One of our translational goals was to evaluate aberrant GSK-3 $\beta$ expression in breast and head and neck tumors as a potential biomarker for selection of cancer patients for clinical trials of GSK-3 inhibitors. To the best of our knowledge, our study is the first to demonstrate aberrant nuclear expression of GSK-3 $\beta$ as a specific marker of cancer cells in breast adenocarcinoma and malignant head and neck tumors (squamous cell and adenoid cystic carcinomas). To extend our initial findings to the clinic, we are planning to evaluate GSK-3 $\beta$ expression in tumor tissues obtained from cancer patients in Phase I/II clinical trials of the GSK-3 inhibitor 9-ING-41. After administration of 9-ING-41 to these patients and subsequent evaluation of treatment response, we will evaluate the clinical utility of nuclear GSK-3 $\beta$ as a potential biomarker for selection of breast and head and neck cancer patients for GSK-3-targeted therapy for prospective clinical trials using paired biopsy samples.

Several reports have shown overexpression of GSK-3 $\beta$ protein levels in malignant tumors of different origin. GSK-3 $\beta$ is weakly expressed in the cytoplasm of benign cells and is rarely detectable in the epithelial cells of benign prostatic tissue whereas cytoplasmic overexpression of GSK-3 $\beta$ was associated with aggressive prostate cancer (29). Using Western blotting, a significant increase of GSK-3 $\beta$ protein expression was found in ovarian adenocarcinomas compared with normal 

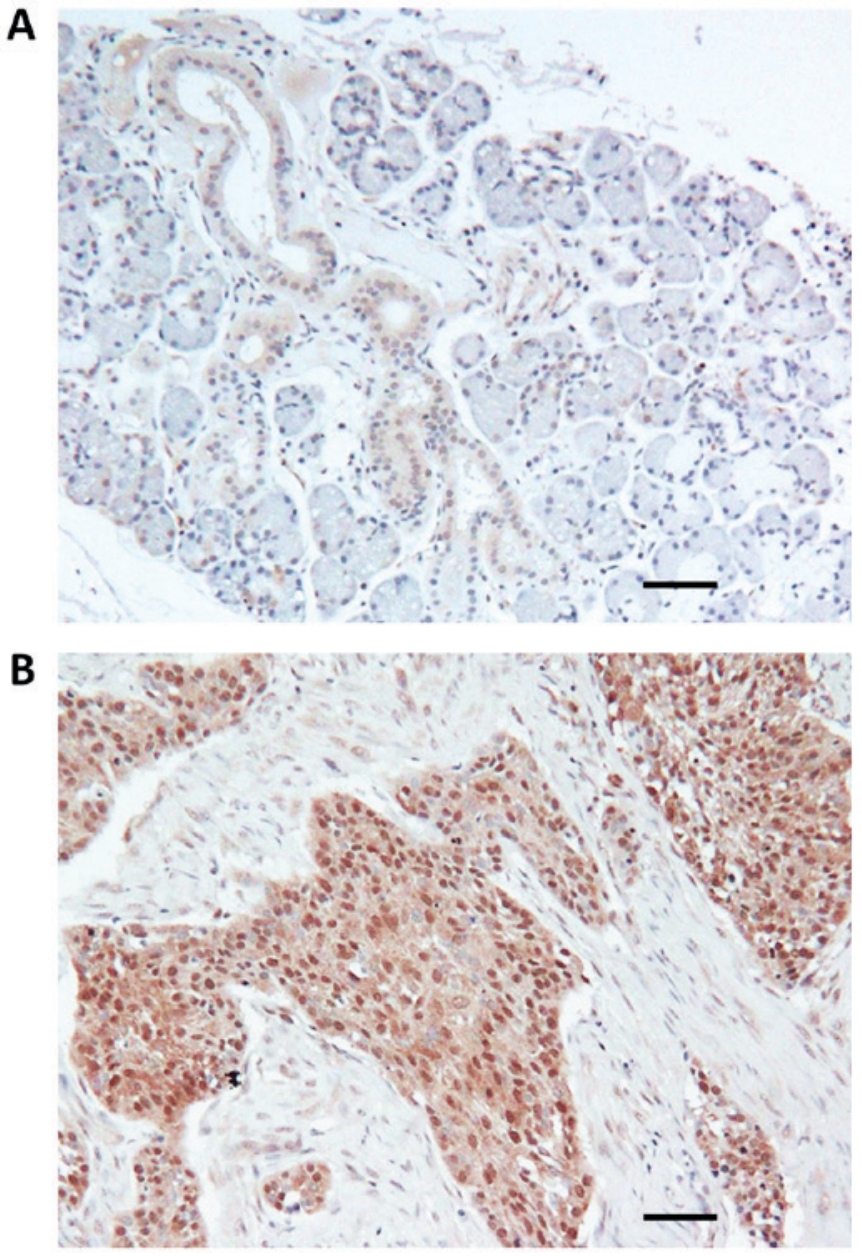

Figure 3. GSK-3 $\beta$ expression in head and neck malignant and benign tissues Representative images of GSK-3 $\beta$ expression and localization in benign salivary gland (A) and squamous cell carcinoma (B). Scale bar, $50 \mu \mathrm{m}$. GSK-3, Glycogen Synthase Kinase-3.

ovaries and benign adenomas/borderline tumors (30). Another study demonstrated that the level of GSK-3 $\beta$ protein expression was significantly higher in colorectal carcinoma tissue than in their normal counterparts (18 of 20 cases), whereas inactive phosphorylated Ser9 GSK-3 $\beta$ was detected in higher levels in normal tissue than in tumors in 17 of 20 cases (8). Recent studies showed that overexpression of GSK-3 $\beta$ protein or its activation were associated with adverse prognosis in patients with glioblastoma $(16)$, lung cancer $(31,32)$, and gastric cancer (33). We found only weak cytoplasmic GSK-3 $\beta$ expression in salivary ducts, whereas GSK-3 $\beta$ staining was hardly detectable in serous and acinar cells. A significant finding of the present study is the presence of aberrant nuclear accumulation of GSK-3 $\beta$ in cancer cells in most cases of breast adenocarcinomas and squamous cell carcinomas. Our results are consistent with another published study showing aberrant nuclear GSK-3 $\beta$ as a specific marker of pancreatic cancer cells whereas nuclear GSK-3 $\beta$ was not detectable in acinar or epithelial pancreatic cells or in PanIN (pancreatic intraepithelial neoplasia) lesions (10). GSK-3 $\beta$ protein nuclear accumulation has also been found in colon (34), bladder (62\% non-invasive and $91 \%$ invasive) (13) and renal cancer (12). It has been shown that only the active form of
GSK-3 $\beta$ accumulates in the nucleus of pancreatic cancer cells and the inhibition of GSK-3 $\beta$ activity depletes its nuclear accumulation via proteosomal degradation whereas the expression level of cytoplasmic GSK-3 $\beta$ is not changed (10). It has also been demonstrated that that nuclear GSK-3 $\beta$ plays an important role in regulating histone modifications, which may contribute to $\mathrm{NF}-\kappa \mathrm{B}$ p $65 / \mathrm{p} 50$ binding to promoters and activating its target genes in cancer cells, leading to increased cancer cell survival (11). Based on this published data and the results presented herein, we hypothesize that nuclear GSK-3 $\beta$ might be the actual target for GSK-3 inhibition in cancer cells, leading to depletion of GSK-3 $\beta$ from the nucleus with a subsequent inhibition of NF- $\mathrm{NB}-$ mediated cancer cell proliferation and survival.

There is now extensive data credentialing GSK-3 $\beta$ as a potential anticancer target in human pancreatic, colon, bladder, breast, ovarian, lung, prostate, thyroid and renal cancer, chronic lymphocytic leukemia, glioblastoma, and neuroblastoma (7-18,26-28,31,32,35-43). Given the broad spectrum potential for a GSK-3 inhibitor in cancer, the identification and validation of patient enrichment biomarkers that select patients most likely to benefit from a GSK-3 inhibitor will be an important component in the clinical development of novel GSK-3 targeted drugs. Our results demonstrate aberrant nuclear accumulation of GSK-3 $\beta$ in a significant number of human breast and squamous cell carcinomas of the head and neck. As IHC staining is an indispensable method for detection of subcellular expression and validation of tumor markers $(44,45)$, the utility of nuclear GSK-3 $\beta$ as an enrichment biomarker will be evaluated by IHC staining in clinical studies of the specific small molecule inhibitor of GSK-3, 9-ING-41 $(26,35,38,42,43)$.

\section{Acknowledgements}

Not applicable.

\section{Funding}

The present study was supported by Cancer Center Support Grant from the Robert H. Lurie Comprehensive Cancer Center of Northwestern University (grant no. 2 P30 CA060553-19 received by $\mathrm{AM}$ and $\mathrm{AU})$.

\section{Availability of data and materials}

All data generated or analyzed during the present study are included in this published article.

\section{Authors' contributions}

AU, AM, VC and FG designed the experiments. AU performed the experiments. AU, MM, TO and TT performed the analysis and interpretation of data. The manuscript was prepared by AU, AM, VC, FG and TO, and all authors contributed to writing and providing feedback.

\section{Ethics approval and consent to participate}

Not applicable. 


\section{Patient consent for publication}

Not applicable.

\section{Competing interests}

The authors declare that there is no conflict of interest.

\section{References}

1. Jemal A, Siegel R, Xu J and Ward E: Cancer statistics, 2010. CA Cancer J Clin 60: 277-300, 2010.

2. Argiris A, Karamouzis M, Raben D and Ferris R. Head and neck cancer. Lancet 371: 1695-1709, 2008.

3. Cohen P and Frame S: The renaissance of GSK3. Nat Rev Mol Cell Biol 2: 769-776, 2001.

4. Diehl JA, Cheng M, Roussel MF and Sherr CJ: Glycogen synthase kinase-3beta regulates cyclin D1 proteolysis and subcellular localization. Genes Dev 12: 3499-3511, 1998.

5. Rubinfeld B, Albert I, Porfir E, Fiol C, Munemitsu S and Polakis P: Binding of GSK3beta to the APC-beta-catenin complex and regulation of complex assembly. Science 272: 1023-1026, 1996.

6. Sears R, Nuckolls F, Haura E, Taya Y, Tamai K and Nevins JR: Multiple Ras-dependent phosphorylation pathways regulate Myc protein stability. Genes Dev 14: 2501-2514, 2000.

7. Ougolkov AV, Fernandez-Zapico ME, Savoy DN, Urrutia RA and Billadeau DD: Glycogen synthase kinase-3beta participates in nuclear factor kappaB-mediated gene transcription and cell survival in pancreatic cancer cells. Cancer Res 65: 2076-2081, 2005.

8. Shakoori A, Ougolkov A, Yu ZW, Zhang B, Modarressi M, Billadeau D, Mai M, Takahashi Y and Minamoto T: Deregulated GSK3beta activity in colorectal cancer: Its association with tumor cell survival and proliferation. Biochem Biophys Res Commun 334: 1365-1373, 2005.

9. Gaisina IN, Gallier F, Ougolkov AV, Kim KH, Kurome T, Guo S, Holzle D, Luchini DN, Blond SY, Billadeau DD and Kozikowski AP: From a natural product lead to the identification of potent and selective benzofuran-3-yl-(indol-3-yl)maleimides as glycogen synthase kinase 3beta inhibitors that suppress proliferation and survival of pancreatic cancer cells. J Med Chem 52: 1853-1863, 2009.

10. Ougolkov AV, Fernandez-Zapico ME, Bilim VN, Smyrk TC Chari ST and Billadeau DD: Aberrant nuclear accumulation of glycogen synthase kinase-3beta in human pancreatic cancer: Association with kinase activity and tumor dedifferentiation. Clin Cancer Res 12: 5074-5081, 2006.

11. Ougolkov AV, Bone ND, Fernandez-Zapico ME, Kay NE and Billadeau DD: Inhibition of glycogen synthase kinase-3 activity leads to epigenetic silencing of nuclear factor kappaB target genes and induction of apoptosis in chronic lymphocytic leukemia B cells. Blood 110: 735-742, 2007.

12. Bilim V, Ougolkov A, Yuuki K, Naito S, Kawazoe H, Muto A, Oya M, Billadeau D, Motoyama T and Tomita Y: Glycogen synthase kinase-3: A new therapeutic target in renal cell carcinoma. Br J Cancer 101: 2005-2014, 2009.

13. Naito S, Bilim V, Yuuki K, Ugolkov A, Motoyama T, Nagaoka A, Kato T and Tomita Y: Glycogen synthase kinase-3beta: A prognostic marker and a potential therapeutic target in human bladder cancer. Clin Cancer Res 16: 5124-5132, 2010.

14. Cao Q, Lu X and Feng Y: Glycogen synthase kinase-3beta positively regulates the proliferation of human ovarian cancer cells. Cell Res 16: 671-677, 2006.

15. Kunnimalaiyaan M, Vaccaro AM, Ndiaye MA and Chen $\mathrm{H}$ : Inactivation of glycogen synthase kinase-3beta, a downstream target of the raf-1 pathway, is associated with growth suppression in medullary thyroid cancer cells. Mol Cancer Ther 6: 1151-1158, 2007.

16. Miyashita K, Kawakami K, Nakada M, Mai W, Shakoori A, Fujisawa H, Hayashi Y, Hamada J and Minamoto T: Potential therapeutic effect of glycogen synthase kinase 3beta inhibition against human glioblastoma. Clin Cancer Res 15: 887-897, 2009.

17. Zhu Q, Yang J, Han S, Liu J, Holzbeierlein J, Thrashe JB and Li B: Suppression of glycogen synthase kinase 3 activity reduces tumor growth of prostate cancer in vivo. Prostate 71: 835-845, 2011

18. Wang Z, Smith KS, Murphy M, Piloto O, Somervaille TC and Cleary ML: Glycogen synthase kinase 3 in MLL leukaemia maintenance and targeted therapy. Nature 455: 1205-1209, 2008.
19. Hoeflich KP, Luo J, Rubie EA, Tsao MS, Jin O and Woodgett JR: Requirement for glycogen synthase kinase-3beta in cell survival and NF-kappaB activation. Nature 406: 86-90, 2000.

20. Aggarwal BB: Nuclear factor-kappaB: The enemy within. Cancer Cell 6: 203-208, 2004

21. Tas SW, Vervoordeldonk MJ and Tak PP: Gene therapy targeting nuclear factor-kappaB: Towards clinical application in inflammatory diseases and cancer. Curr Gene Ther 9: 160-170, 2009.

22. Medina M and Castro A: Glycogen synthase kinase-3 (GSK-3) inhibitors reach the clinic. Curr Opin Drug Discov Devel 11: 533-543, 2008

23. Walz A, Ugolkov A, Chandra S, Kozikowski A, Carneiro BA, O'Halloran TV, Giles FJ, Billadeau DD and Mazar AP: Molecular pathways: Revisiting glycogen synthase kinase- $3 \beta$ as a target for the treatment of cancer. Clin Cancer Res 23: 1891-1897, 2017.

24. Rizzieri DA, Cooley S, Odenike O, Moonan L, Chow KH, Jackson K, Wang X, Brail L and Borthakur G: An open-label phase 2 study of glycogen synthase kinase-3 inhibitor LY2090314 in patients with acute leukemia. Leuk Lymphoma 57: 1800-1806, 2016.

25. Dignam JD, Lebovitz RM and Roeder RG: Accurate transcription initiation by RNA polymerase II in a soluble extract from isolated mammalian nuclei. Nucleic Acids Res 11: 1475-1489, 1983.

26. Ugolkov A, Gaisina I, Zhang JS, Billadeau DD, White K, Kozikowski A, Jain S, Cristofanilli M, Giles F, O'Halloran T, et al: GSK-3 inhibition overcomes chemoresistance in human breast cancer. Cancer Lett 380: 384-392, 2016.

27. Quintayo MA, Munro AF, Thomas J, Kunkler IH, Jack W, Kerr GR, Dixon JM, Chetty U and Bartlett JM: GSK3 $\beta$ and cyclin D1 expression predicts outcome in early breast cancer patients. Breast Cancer Res Treat 136: 161-168, 2012.

28. Shin S, Wolgamott L, Tcherkezian J, Vallabhapurapu S, Yu Y, Roux PP and Yoon SO: Glycogen synthase kinase- $3 \beta$ positively regulates protein synthesis and cell proliferation through the regulation of translation initiation factor $4 \mathrm{E}$-binding protein 1 . Oncogene 33: 1690-1699, 2014.

29. Darrington RS, Campa VM, Walker MM, Bengoa-Vergniory N, Gorrono-Etxebarria I, Uysal-Onganer P, Kawano Y, Waxman J and Kypta RM: Distinct expression and activity of GSK-3 $\alpha$ and GSK-3 $\beta$ in prostate cancer. Int J Cancer 131: E872-E883, 2012.

30. Rask K, Nilsson A, Brännström M, Carlsson P, Hellberg P, Janson PO, Hedin L and Sundfeldt K: Wnt-signalling pathway in ovarian epithelial tumours: increased expression of beta-catenin and GSK3beta. Br J Cancer 89: 1298-1304, 2003.

31. Vincent EE, Elder DJ, O'Flaherty L, Pardo OE, Dzien P, Phillips L, Morgan C, Pawade J, May MT, Sohail M, et al: Glycogen synthase kinase 3 protein kinase activity is frequently elevated in human non-small cell lung carcinoma and supports tumour cell proliferation. PLoS One 9: e114725, 2014.

32. Zeng J, Liu D, Qiu Z, Huang Y, Chen B, Wang L, Xu H, Huang N, Liu L and Li W: GSK3 $\beta$ overexpression indicates poor prognosis and its inhibition reduces cell proliferation and survival of non-small cell lung cancer cells. PLoS One 9: e91231, 2014

33. Cho YJ, Yoon J, Ko YS, Kim SY, Cho SJ, Kim WH, Park JW, Youn HD, Kim JH and Lee BL: Glycogen synthase kinase-3 $\beta$ does not correlate with the expression and activity of $\beta$-catenin in gastric cancer. APMIS 118: 782-790, 2010.

34. Salim T, Sjölander A and Sand-Dejmek J: Nuclear expression of glycogen synthase kinase- $3 \beta$ and lack of membranous $\beta$-catenin is correlated with poor survival in colon cancer. Int J Cancer 133 : 807-815, 2013.

35. Pal K, Cao Y, Gaisina IN, Bhattacharya S, Dutta SK, Wang E, Gunosewoyo H, Kozikowski AP, Billadeau DD and Mukhopadhyay D: Inhibition of GSK-3 induces differentiation and impaired glucose metabolism in renal cancer. Mol Cancer Ther 13: 285-296, 2014.

36. Carter YM, Kunnimalaiyaan S, Chen H, Gamblin TC and Kunnimalaiyaan M: Specific glycogen synthase kinase-3 inhibition reduces neuroendocrine markers and suppresses neuroblastoma cell growth. Cancer Biol Ther 15: 510-515, 2014.

37. Duffy DJ, Krstic A, Schwarzl T, Higgins DG and Kolch W: GSK3 inhibitors regulate MYCN mRNA levels and reduce neuroblastoma cell viability through multiple mechanisms, including p53 and Wnt signaling. Mol Cancer Ther 13: 454-467, 2014.

38. Hilliard TS, Gaisina IN, Muehlbauer AG, Gaisin AM, Gallier F and Burdette JE: Glycogen synthase kinase $3 \beta$ inhibitors induce apoptosis in ovarian cancer cells and inhibit in-vivo tumor growth. Anticancer Drugs 22: 978-985, 2011. 
39. Kotliarova S, Pastorino S, Kovell LC, Kotliarov Y, Song H, Zhang W, Bailey R, Maric D, Zenklusen JC, Lee J and Fine HA: Glycogen synthase kinase-3 inhibition induces glioma cell death through c-MYC, nuclear factor-kappaB, and glucose regulation. Cancer Res 68: 6643-6651, 2008.

40. Kunnimalaiyaan M, Vaccaro AM, Ndiaye MA and Chen $\mathrm{H}$ : Inactivation of glycogen synthase kinase-3beta, a downstream target of the raf-1 pathway, is associated with growth suppression in medullary thyroid cancer cells. Mol Cancer Ther 6: 1151-1158, 2007.

41. Zhu Q, Yang J, Han S, Liu J, Holzbeierlein J, Thrasher JB and Li B: Suppression of glycogen synthase kinase 3 activity reduces tumor growth of prostate cancer in vivo. Prostate 71: 835-845, 2011.

42. Ugolkov A, Qiang W, Bondarenko G, Procissi D, Gaisina I, James CD, Chandler J, Kozikowski A, Gunosewoyo H, O'Halloran T, et al: Combination treatment with the GSK-3 inhibitor 9-ING-41 and CCNU cures orthotopic chemoresistant glioblastoma in patient-derived xenograft models. Transl Oncol 10: 669-678, 2017.
43. Ugolkov AV, Bondarenko GI, Dubrovskyi O, Berbegall AP, Navarro S, Noguera R, O'Halloran TV, Hendrix MJ, Giles FJ and Mazar AP: 9-ING-41, a small molecule glycogen synthase-3 inhibitor, is active in neuroblastoma. Anticancer Drugs 29: 717-724, 2018.

44. Kim SW, Roh J and Park CS: Immunohistochemistry for pathologists: Protocols, pitfalls and tips. J Pathol Transl Med 50: 411-418, 2016.

45. Cheuk W and Chan JK: Subcellular localization of immunohistochemical signals: Knowledge of the ultrastructural or biologic features of the antigens helps predict the signal localization and proper interpretation of immunostains. Int J Surg Pathol 12: $185-206,2004$

This work is licensed under a Creative Commons Attribution-NonCommercial-NoDerivatives 4.0 International (CC BY-NC-ND 4.0) License. 